November 2013

\title{
Genocide on Trial: Case Note and Extracts of "Circuito Camps" Judgment
}

\author{
María Belén Riveiro \\ CONICET-Genocide Studies Centre - National University of Tres de Febrero-Argentina \\ Luciana Rosende \\ CONICET-Genocide Studies Centre - National University of Tres de Febrero-Argentina \\ Lior Zylberman \\ CONICET-Genocide Studies Centre - National University of Tres de Febrero-Argentina
}

Follow this and additional works at: https://digitalcommons.usf.edu/gsp

\section{Recommended Citation}

Belén Riveiro, María; Rosende, Luciana; and Zylberman, Lior (2013) "Genocide on Trial: Case Note and Extracts of "Circuito Camps" Judgment," Genocide Studies and Prevention: An International Journal: Vol. 8: Iss. 1: Article 9.

DOI: http://dx.doi.org/10.5038/1911-9933.8.1.7

Available at: https://digitalcommons.usf.edu/gsp/vol8/iss1/9

This Document is brought to you for free and open access by the Open Access Journals at Digital Commons @ University of South Florida. It has been accepted for inclusion in Genocide Studies and Prevention: An International Journal by an authorized editor of Digital Commons @ University of South Florida. For more information, please contact digitalcommons@usf.edu. 


\title{
Genocide on Trial:
}

\section{Case Note and Extracts of "Circuito Camps" Judgment'}

\author{
María Belén Riveiro, Luciana Rosende and Lior Zylberman \\ Genocide Studies Centre - National University of Tres de Febrero-Argentina
}

\begin{abstract}
Note: Since 2006, several Argentine courts have tried the crimes committed during the 1976 dictatorship. While in most countries these crimes are usually tried by International Tribunals or by Mixed Jurisdiction Tribunals, in Argentina national courts have been responsible of this task. We will analyze a judgment that considers that these crimes entail the commission of the crime of Genocide.
\end{abstract}

The public trial for crimes committed during the civilian-military dictatorship in Argentina (1976-1983) in the network of clandestine detention, torture and extermination centers ("clandestine centers") known as the "Camps Circuit" began on September 12, 2011. The trial was conducted by Federal Criminal Oral Court No. 1 of La Plata, composed of Judges Mario Portela and Roberto Falcone and presided over by Judge Carlos Rozanski. After hearings lasting over a year, the judgment was read out before a packed courtroom on December 19, 2012, and the reasoning of the judgment were made known on March 25, 2013.

Although the existence of genocide in Argentina had been recognized in several previous judgments, ${ }^{2}$ this was the first case in which the offenses were described as genocide at the unanimous request of the prosecution and the various complainants. In the words of the Court's judgment: "Whereas the conduct of the accused, being clearly intended to exterminate a national group, entails the commission of the International Crime of Genocide (as defined by Article $2 \mathrm{a}, \mathrm{b}, \mathrm{c}$ and e of the Convention on the Prevention and Punishment of the Crime of Genocide, which was ratified by Decree 6,286, in accordance with Art. 118 of the Constitution), a sentence for that offense is appropriate in each case. Notwithstanding the foregoing, by majority, in order not to violate the principle of congruence because the defendants were not investigated for this crime, which was only introduced in the allegations, it is appropriate to apply the categories of crimes and the penalties provided for in domestic law, all of which constitute crimes against humanity, with the full Court in agreement with the latter categorization" (p. 1746) ${ }^{3}$.

Since the reopening of trials for dictatorship-era human rights violations in 2003, other rulings had already acknowledged that these crimes were committed "in the context of genocide". The decision of the Federal Criminal Oral Court No. 1 of La Plata agreed with the petitions of the complainants and the prosecution. According to the Court, crimes of genocide took place because they were committed against a national group, and due to the systematic crimes of homicide, illegal deprivation of liberty, aggravated torture, abduction, detention and hiding of minors and the falsification of their identities, each of which was proven at the trial.

Judgment was delivered for crimes committed in the network of clandestine centers known as the "Camps Circuit", named by the survivors after the former police chief of Buenos Aires province, General Ramón Camps, ${ }^{4}$ under whose command these clandestine centers operated. The systematic nature of these crimes was confirmed by the fact that each establishment had 'functional relations' with the rest, although they did not always followed a common pattern. The judgment exemplified the way the circuit functioned: "Based on the above, we can trace a pattern of the way the so-called 'Camps Circuit' worked within the overall design or framework of repression: once they had been kidnapped, the victims were housed in the Investigation Squad (operations center), then transferred to the Arana Detachment (which [...] functioned as a torture and extermination center), and finally taken to the 5th Precinct (a holding center for detainees)" (p. 305).

This circuit functioned in nine districts of Greater Buenos Aires and the city of La Plata (capital of Buenos Aires province) and comprised at least 29 clandestine centers. The trial concerned crimes committed in the 5th Precinct of La Plata, the Investigation Unit of La Plata, the Arana Detachment, the Police Substation of Don Bosco (known as 'Puesto Vasco' or 'Basque Center'), the Tactical Operations Center I in Martinez and the San Justo Brigade.

The accused were tried for the kidnapping and torture of 280 persons, many of whom are still missing, and 37 homicides that were proven through the participation of the Argentine Forensic Anthropology Team ${ }^{5}$, who

María Belén Riveiro, Luciana Rosende and Lior Zylberman, "Genocide on Trial: Case Note and Extracts of "Circuito Camps" Judgment," Genocide Studies and Prevention 8, 1 (Spring 2013): 57-66. @2013 Genocide Studies and Prevention. http://dx.doi. org/10.5038/1911-9933.8.1.7 
found and identified the remains of hundreds of disappeared persons, for which the team was commended by the Court. The accused were not only tried for crimes committed within the detention centers, but also for an attack on the 'house on 30th Street' in the city of La Plata, where the Montoneros organization ${ }^{6}$ had a clandestine printing press. During this attack, three people were murdered and baby Clara Anahí Mariani Teruggi, the three-month-old granddaughter of a founder of the Grandmothers of Plaza de Mayo, was abducted. Clara has never been found, so, in the opinion of the presiding judge Carlos Rozanski, the crimes of kidnapping and falsifying the child's identity are still being perpetrated. Referring to the permanent nature of certain crimes, Judge Rozanski considered that the abduction and identity theft continue to be committed until the victims regain their true identity.

The case opened with twenty-six defendants, three of whom died before judgment was delivered (Ibérico Saint Jean ${ }^{7}$, the former de facto governor of Buenos Aires Province from 1976 to 1981, Alejandro Arias Duval, and Rubén Páez). Of the remaining twenty-three, sixteen were sentenced to life imprisonment and the rest were sentenced to between two and twenty-five years. Some of the accused were acquitted of certain crimes because their responsibility had not been proven. Among the accused to be tried were Jorge Antonio Bergés and Jaime Lamont Smart. The former was a police physician in the Province of Buenos Aires and was accused of delivering babies in clandestine centers, participating in the torture of detainees, and the appropriation of minors. Smart was a lawyer and Minister of Government of the Province of Buenos Aires between 1976 and 1979, and was the first civilian official ${ }^{8}$ of the dictatorship to be convicted of first-degree murder, illegal confinement and torture, on 43 counts. His conviction allows a deeper understanding of the relations between civil society and the military power of the dictatorship: "The consummation of the crimes described here would not have been possible without the indispensable and unavoidable assistance of the Minister, providing material and financial resources and police forces from the province. That is to say, Smart made the entire administrative structure of his ministry available for the genocidal plan" (p. 1431).

It is important to note the role of testimony in these trials, at which about 400 victims, both survivors and family members gave evidence. Moreover, for the first time, the hearings included video recordings of previous statements by Adriana Calvo, former president of the Association of Former Detainees and Disappeared, who died in 2010, and Jorge Julio López, a survivor who testified at the trial of Miguel Osvaldo Etchecolatz ${ }^{9}$ in 2006 and disappeared shortly afterwards without trace. The López case is unique in present-day Argentina and remains unsolved.

\section{Grounds of the judgment}

In order to understand the reasons why the 1976-1983 dictatorship was established, the Court reconstructed the modus operandi of the National Reorganization Process, as the military who took power named it. In describing the historical context, the Court took into account the situation prior to the coup of March 24, 1976: "Twenty-seven South American countries endured coups throughout the twentieth century. Argentina was not immune to this phenomenon, and there were breaks in constitutional government in 1930, 1943, 1955, 1966 and 1976." (p. 240) The grounds included a survey of the historical development of the country since the overthrow of Juan Domingo Perón in 1955 until his death during his third presidency in 1974, when power passed to his wife María Estela Martínez de Perón, under whom the Armed Forces took on an increasingly bigger role in repressing protest movements: “... on February 5, 1975, Decree No 261 was promulgated ordering military operations to neutralize and / or annihilate the action of subversive elements acting in Tucumán province (known as "Operation Independence", and considered to be the first stage of annihilation using State structures)” (p. 243).

Reference was also made to the existence of documents and manuals - many of which were incorporated as evidence at trial - on how to carry out 'counterinsurgency operations', showing long-standing planning for just such a scenario: "After the repression carried out under Operation Independence, the army already had secret counterinsurgency operations manuals, like RC-9-1, known as "Operations against subversive elements" (used as a trial exhibit). This book was an outright doctrine of extermination. Among the most relevant chapters we quote Chapter IV, Section I "Guidelines" which explains that 'combat power should be applied with the utmost violence to annihilate subversive criminals wherever they are ... Military action is always violent and bloody, but it must be justified and supported by psychological operations'; 'the guiding concept is that the subversive delinquent wielding weapons must be destroyed, because when the Armed Forces undertake operations against these criminals, they should not interrupt the fight or accept surrenders' (Art. 4003 para. I of the Manual)" (p. 244). 
The grounds on which the Court described these crimes as genocide took into account both international law and the Argentine Armed Forces own directives. It historicized the concept of genocide from the pioneering work of Raphael Lemkin to more recent research, both international and national, selecting several arguments of the judgments of the Nuremberg Tribunal and the International Criminal Tribunal for Rwanda. In this way, the judges drew a comparative analysis of the Nazis' 'Final Solution' and the Argentine case: "The military junta organized a perfect block of forces coordinated by multiple directives (Navy Directive No. 1, "S"/ 75 and Placintara / 75; Army Directives No. 404/75, 504/77 and 604/79; Aeronautics, Capacity Plan / 75) to remove an "enemy" constructed by the Junta, created by the Junta's own rise to power, the "hostis judicatus." The enemy was eliminated employing methods amazingly similar to those of the "Final Solution" (Endlösung der Judenfrage) used for the systematic genocide of Jews in Europe" (p. 266) $)^{10}$.

By comparing the Argentine experience with other exterminations, such as those of the Armenian and Jewish people, the Court stated that "As mentioned in this Court's previous judgments, it is not a question of competing over which nation has suffered more or which community has borne the greatest number of victims. It is, rather, a matter of correctly identifying phenomena that, despite contextual differences and variations in time and space, show a similarity that must be acknowledged." (p. 1714)

While comparisons were made with other historical processes in which genocide was perpetrated, the Court emphasized the particularities of the extermination perpetrated in Argentina: "In our country the coup leaders imposed their own style of genocide. Through the annihilation of the opposition they aimed to refound society and give birth to a new one. Daniel Feierstein calls this «reorganizing genocide»; 'the Argentine genocide can be thought of as one of the most successful and cost-effective instances of «reorganizing genocide» in terms of destroying and rebuilding the social fabric. An interesting innovation is that, unlike earlier genocidal processes or even other military dictatorships in the region, this self-styled «National Reorganization Process» was a novelty in relation to both other military dictatorships and previous genocidal processes. The reengineering was designed to restore «Western and Christian values» to society, The annihilation in Argentina was not spontaneous, it was no accident, it was not irrational: it was the systematic destruction of a «substantial part» of the Argentine national group with the aim of transforming it as such, redefining its way of being, its social relationships, its destiny, its future"'(p. 268).

The Court emphasized that this 'reengineering' work placed particular emphasis on government propaganda, and control of the media and the education system. "One of the practices carried out for this purpose was the systematic burning of books. 'The purging fire,' as some call it, reached several libraries in Córdoba, where books by Pablo Neruda, Julio Godio and Leon Trotsky, among others, were burned (...) [and] the Constancio Vigil public library in Rosario where several thousand of its 55,000 books were burned (the library's Executive Committee was kidnapped in 1977) and [the publishing company] Centro Editor de América Latina (CEAL) lost nearly a million and a half books and booklets. And again the Nazi analogy is clear" (p. 283).

In giving its reasons for describing as genocide the offenses the accused were convicted of, the Court took as precedents the first trials of the members of the military junta conducted shortly after the return of democracy. In these it had been demonstrated that "the system implemented - kidnapping, interrogation under torture, clandestine and illegitimate deprivation of liberty and, in many cases, the elimination of the victims - was substantially the same throughout the territory of the Nation and prolonged over time." (p. 1712) The systematic nature of the repression was also demonstrated in a trial conducted in 1986 in which cases from the "Camps Circuit" were heard: "This description given by the Court in the decision we have just cited together with the other descriptions of the same elements recorded there and those then developed in Case 44 in which Etchecolatz was convicted on 91 counts of torture, marked the beginning of a formal, deep and official recognition of the extermination plan carried out by those governing the country during that period" (pp. 1712-1713).

The Court also took into account its earlier decisions in Cases 2251/06 (Etchecolatz, Miguel Osvaldo s/ homicidio calificado) and 2901/09 (Dupuy, Abel David y otros, s/homicidio, tormentos, privación ilegal de la libertad), where it had already made clear that it understood that genocide had been committed in Argentina during the civilian-military dictatorship. It also considered as precedents, judgments for crimes committed in other detention centers.

In this trial, the crime of genocide was understood as follows: "genocide is the denial of the right of existence of entire human groups, just as homicide is the denial of the right to life of individual human beings" (p. 1710). The judgment applied the United Nations Convention on the Prevention and Punishment of the 
Crime of Genocide, which acknowledged the disputes that surrounded its interpretation and its exclusion of political groups as protected groups: "an interesting question has arisen as a result, especially with regard to what happened in our country during the civilian-military dictatorship that began in 1976, the question of whether the tens of thousands of victims of state terrorism did or did not form part of the so-called 'national group' referred to in the Convention. (...) the answer must be affirmative, beyond the legal qualification that has been given to the facts in that case or in this for the purpose of imposing the conviction and sentence" (p. 1712).

The Court explained its understanding of "national group" when it stated that "... the term 'national group' is perfectly valid for defining what happened in Argentina, since the perpetrators intended to destroy a given set of social relations in a State in order to produce a change substantial enough to alter the life of the whole. Given the inclusion of the term "in whole or in part" in the definition of the 1948 Convention, it is clear that the Argentine national group was annihilated "in part" and that this part was substantial enough to alter the social fabric of the nation itself" (p. 1713).

After reading the sentences, the Court also considered other issues. One suggestion it made was that, due to the repeated references of various plaintiffs to sexual offenses committed in the clandestine centers mentioned in the judgment, and "taking into account recent case law and doctrinal developments, which consider that these crimes were sufficiently independent to be considered as part of a systematic plan of repression and therefore not subject to statutes of limitation, as well as the various testimonies received that bear witness to these criminal acts, we understand that it falls to us to convey to the aforementioned Federal Courts the need expressed by the prosecution that sexual offenses committed within the framework of crimes against humanity, should be investigated within the framework and context in which they were committed" (p. 1739). The Court also urged the provincial Executive to close police stations that functioned as Clandestine Detention Centers so that they can become 'sites of memory'.

It is suggestive that the final observation of the Court is dedicated to the newspaper La Nación. ${ }^{11}$ Throughout the course of the trial, this morning broadsheet published several editorials and news stories about the hearings. The Court found that these publications reflected the facts fallaciously, "in an attempt to improve the procedural position of one of the accused" (p. 1744), and alleged that this publication was the medium used to convey threats against two members of the Court so as to influence the final judgment. Although no legal action has been taken, the judges' comments show the significance and importance of this trial as well as media interference in the judicial system.

Furthermore, testimony given at trial provided important information on the forced transfer of Argentina's only newsprint company, Papel Prensa, after the kidnapping of owners of the company and their families, some of whom are still missing. ${ }^{12}$ The Court sent these statements to the court that is handling the Papel Prensa Case.

The Court also ordered separate recordings of testimonies obtained during the trial to be sent to other courts to be incorporated into various ongoing cases. It urged investigation into the involvement of other areas of civil society, such as the Church and the judiciary, for example, to assess "the alleged responsibility of Emilio Grasselli, secretary to the Military Vicar-General, and of officials at the San José Seminary in La Plata" (p. 1781). The San José Seminary was mentioned in the testimony of several survivors of the 5th Precinct as a place that provided food for detainees held in this clandestine center. This is just one of many examples of the weight that the Court gave to their testimony as proof: "These hidden actions [referring to the clandestine nature of the detention centers] mean that in many cases the documentary evidence of the crimes committed is flimsy, and testimonial evidence acquires significant importance. It is almost laughable to pretend that orders or instructions to violate human rights would have been placed on record in unclassified or public documents" (p. 286).

To conclude, we believe that this Court views justice not merely in terms of punishment. It also takes into account the social effects that go beyond the scope of the judgments of courts, defining law as a producer of truth. Therefore, the Court mulled over the importance of considering the distinctive characteristics of the offenses prosecuted in this trial to contribute to a deeper understanding of the past. That is why the Court highlights the State's responsibility to accept that in Argentina there was not just a succession of isolated events but that these crimes were part of a larger project characterized as genocide. To illustrate this point, the court stressed the need to "understand the difference in context between the theft of a watch in public, with a stay in a secret detention center during the civilian-military dictatorship, [which is] essential to understanding not only the legal significance to be given to the stories and collected evidence, but to properly analyzing the rest of the offenses covered here, including disappearances and murders" (p. 325). 
Judgment Extract: "ALMEIDA, Domingo y otros s/ Inf. arts. 80, 139, 142, 144, 146, 45, 54 y 55 del C.P."

\section{The crime of genocide}

In their pleadings, both complainants and prosecutors alluded to the facts ruled on in this trial, describing them as committed in the context of genocide. This Court, both in its previous and current composition, and recently when sentencing in Case 2901 (Dupuy), made its position clear that in Argentina a genocide took place during the civilian-military dictatorship. Once again, it is worth recalling briefly the historical circumstances in which the concept of genocide came to be incorporated [into international law] and then partially incorporated into the respective [Genocide] Convention.

After World War II, an international debate began on the most appropriate way of defining the concept of genocide. A milestone in that debate, which has continued until this day, was the Convention on the Prevention and Punishment of the Crime of Genocide adopted by the United Nations in December 1948. The Convention, in turn, has an antecedent that cannot be overlooked because of its implications for the conclusions of this Court in today's ruling. As a result of the events occasioned by Nazism, the United Nations, in Resolution 96 (I) of December 11, 1946, invited the Member States to enact the necessary legislation for the prevention and punishment of genocide.

The resolution states: "Genocide is a denial of the right of existence of entire human groups, as homicide is the denial of the right to live of individual human beings; such denial of the right of existence shocks the conscience of mankind, results in great losses to humanity in the form of cultural and other contributions represented by these human groups, and is contrary to moral law and to the spirit and aims of the United Nations. Many instances of such crimes of genocide have occurred when racial, religious, political and other groups have been destroyed, entirely or in part." It goes on to say: “The General Assembly, therefore, [...] Affirms that genocide is a crime under international law which the civilized world condemns, and for the commission of which principals and accomplices - whether private individuals, public officials or statesmen, and whether the crime is committed on religious, racial, political or any other grounds-are punishable."

It is clear from this transcription-and particularly relevant to this point-that in the resolution cited, the international community, horrified by the knowledge of the crimes committed by the Nazis during World War II, did not hesitate to include "political and other groups" [sic] in the first paragraph transcribed, followed by “... political or any other grounds." [sic]

Moreover, Article 2 of the first draft of the United Nations Convention on the Prevention and Punishment of the Crime of Genocide stated that: "In this Convention genocide means any of the following deliberate acts committed with the intent to destroy a national, racial, religious or political group, on grounds of the national or racial origin, religious belief, or political opinion of its members: (1) Killing members of the group; (2) Impairing the physical integrity of members of the group; (3) Inflicting on members of the group measures or conditions of life aimed at causing their deaths; Imposing measures intended to prevent births within the group." As can be observed, this draft referred to political groups as well as to the political opinions of a group's members.

However, due to the prevailing political situation in some States, the Convention approved in 1948 defined the crime as follows: "genocide means any of the following acts committed with intent to destroy, in whole or in part, a national, ethnical, racial or religious group as such: a) Killing members of the group, b) Causing serious bodily or mental harm to members of the group, c) Deliberately inflicting on the group conditions of life calculated to bring about its physical destruction in whole or in part; $d$ ) Imposing measures intended to prevent births within the group; e) Forcibly transferring children of the group to another group."

In this new version, it can be observed that both political groups and political grounds were excluded from the new definition. Subsequently, an interesting question was raised about what happened in our country during the civilian-military dictatorship that began in 1976 and, in particular, whether the tens of thousands of victims of state terrorism are members or not of the so-called "national group" referred to in the Convention.

As stated in those cases following the judgment delivered in the "Etchecolatz" case, 2251/06, and ratified in the recent Dupuy case mentioned above, an affirmative answer is warranted since the events in our country in the period in question must be categorized as genocide, beyond the legal qualification that has been given to the facts in that case or in this for the purpose of imposing the conviction and sentence. The foregoing statement derives from the analysis that follows and is the result of the use of elementary logic.

In a historic ruling in Case 13/84, the trials of the military junta leaders, the mechanics of mass destruction implemented by those calling themselves the "National Reorganization Process" was considered to have been proven. 
As stated in Case 13/84, in which former members of the military juntas were convicted: “The system implemented-kidnapping, interrogation under torture, clandestine and illegitimate deprivation of liberty, and, in many cases, the elimination of the victims - was substantively the same throughout the territory of the Nation and was prolonged over time."

This definition was reproduced in the judgment delivered on December 2, 1986 by the National Criminal and Correctional Appeals Chamber of the Federal Capital of Argentina, in Case No. 44, and both were included in the trial by being read aloud. In addition, it later became clear in the same Case 13 that this "system" was widely adopted from March 24, 1976 onwards (Chapter XX, Case 13/84).

This description given by the Court in the decision we have just cited together with the other descriptions of the same elements recorded there and those then developed in Case 44 in which Etchecolatz was convicted on 91 counts of torture, marked the beginning of a formal, deep and official recognition of the extermination plan carried out by those governing the country during that period.

It is precisely this acceptance of both the facts and the Argentine State's responsibility for them that gives rise to a process of "truth-production." The latter must include recognition of the fact that genocide took place in our country and that crimes against humanity did not occur as isolated events but were part of a bigger plan. As to whether what happened in our country should be framed in the concept of "national group" in the wording finally adopted in Art. II of the Convention, this Court has already ratified its affirmative position in the Dupuy judgment.

However, it should be remembered that as mentioned by Daniel Feierstein, a renowned expert on the subject: “...'the term "national group" is absolutely valid for analyzing what happened in Argentina since the perpetrators set out to destroy part of the social fabric in order to produce a sufficiently substantial change so as to affect the State in its entirety: "Given the inclusion of the term 'total or partial' in the definition of the 1948 Convention, it is evident that the Argentinean national group has been annihilated 'partially' and to a sufficiently substantial extent as to alter the social fabric of the nation... the annihilation in Argentina was not spontaneous, was not fortuitous, was not irrational: this was the systematic destruction of a 'substantial part' of the Argentine national group, with the intention of transforming it as such, redefining its way of life, its social relations, its destiny, its future" (Daniel Feierstein / Guillermo Levy. Hasta que la muerte nos separe. Prácticas sociales genocidas en América Latina, [Till death do us part. Genocidal Social Practices in Latin America] Ediciones Al margen. Buenos Aires, 2004, p. 76).

Our understanding, in the light of what has gone before, is that as expected we are dealing not with a mere succession of crimes, but rather with something significantly bigger that is appropriately termed "genocide." However it needs to be made clear that this cannot and should not be interpreted as a disregard for the important differences between what happened in Argentina and the exterminations that claimed the lives of more than a million Armenians (in the first genocide of the twentieth century, which began in 1915), or the millions of victims of Nazism during World War II, or the slaughter of a million people in Rwanda in 1994, to cite just a few notorious examples.

As mentioned in this Court's previous judgments, it is not a question of competing over which nation has suffered more or which community has borne the greatest number of victims. It is, rather, a matter of correctly identifying phenomena that, despite contextual differences and variations in time and space, show a similarity that must be acknowledged. Indeed, as Feierstein concludes in discussing the reasons why different historical processes can be identified in the same terms, “...using the same concept does imply arguing the existence of a common thread originating in a technology of power in which the 'negation of the other' is taken to extremes: physical disappearance (of their bodies) and symbolic disappearance (the memory of their existence)" (op cit p.88). In a more recent paper, the same author conceptualizes a type of genocide he calls "reorganizing genocide", which he derives from the experience of Nazism, and which is appropriate for analyzing this issue. He notes that one of the distinctive features of this variety of genocide is the use of concentration camps, which serve as a fundamental tool in the process.

Referring to what happened in our own country, Feierstein says: "the Argentine genocide - although much smaller in scale - can be thought of as one of the most successful and cost-effective instances of 'reorganizing genocide' in terms of destroying and rebuilding the social fabric. An interesting innovation is that, unlike earlier genocidal processes or even other military dictatorships in the region, this self-styled 'National Reorganization Process' a novelty in relation to both other military dictatorships and previous genocidal processes" (Daniel Feierstein. Genocide as a social practice: From Nazism to Argentina, p. 356. Fondo de Cultura Económica. Buenos Aires 2007). He also noted that a new feature of this type of genocide is 
that it sets out to transform social relations within an existing nation state, but in a manner so profound that it succeeds in changing the way society functions (p. 358).

That "reorganizing" intention of the modern genocide model can be found in some of the many declarations made to the press during the years of the (National Reorganization) Process by its leaders. A small sample of these should be sufficient to lend weight to the concept described.

"Once the sense of nation, neighborhood, friendship and brotherhood had disappeared, everything gradually became cloudy and dirty. It ended up in the mud and in the mud, men fought out of love for God, Country and family. It is love that prioritizes and legitimizes the actions of the soldiers (...). In the war we are fighting, love for the social body that we want to protect has been paramount in all our actions. Because, ultimately, Marxism is the modern heresy and what we are seeing is the most recent action in the constant war between Good and Evil” (p. 21) Camps, Ramon J. A.Caso Timerman, Punto Final, (Timerman Case. Full Stop.) Editorial Tribuna Abierta, 1982.

"Subversion means subverting values, the guerrilla being only one objective consequence of this. When values are disrupted, there is subversion (...) In addition to combating subversion, we need to govern, and government begins by clarifying the traditional values of our way of life" (Videla, Jorge Rafael in La Prensa, May 13, 1976).

"The fight will take place in all fields, in addition to the strictly military one. Destructive and anti-national action in culture, in the media, in the economy, in politics or in trade unionism will not be tolerated" (Videla, Jorge Rafael in La Prensa, July 8, 1976).

"[It's good that we see ourselves] for what we are, a constituent part of a transcendent phenomenon that goes beyond us as a nation [...] Over the past thirty years a true world war has been developing, a war that has man's spirit as its battleground of choice [...] In the midst of this war of cultures and countercultures, Argentina has been going through a time of acute weakness in its social controls, and every act of illicit seduction that has been committed against the people, every distortion, every lie, has increased the growing sense of disappointment through which, eventually, the destructive gospel of totalitarianism could be expected to seep [...] Words, betraying their meanings, have disrupted our ability to reason and even the Word of God has been used by these murderers to invent a theology justifying violence [...] We have to win back the West. But what is the West? No one will find it on the map. The West is now an attitude of the soul that is no longer tied to any geographical place." (Massera, Emilio E., in La Prensa, May 16, 1977).

"Within our way of life, nobody is deprived of freedom just because they think differently; but we consider it a serious crime to attack the Western and Christian way of life and try to change it for one that is completely alien to us. The aggressor in this type of struggle is not just the bomber, the gunman or the kidnapper. At the intellectual level, it is anyone that tries to change our way of life by promoting subversive ideas; in other words, who tries to subvert, change or disrupt [our] values [...] A terrorist is not just someone who kills with a gun or a bomb, but anyone who spreads ideas that are contrary to Western and Christian civilization" (Videla, Jorge Rafael in La Prensa, December 18, 1977).

“The March 1976 document clearly defined Argentina as a bulwark of Western Christian civilization. This definition, which is based on the assertion of its own values, is not conditioned by the haphazard and erratic attitudes of other Western nations. For us, the West is a historical becoming rather than a geographical location. A becoming born in Greece and projected through Rome, and fertilized by the Catholic religion. The West is to be found wherever ideas of freedom and faith in Christ govern men's actions" (Brigadier O. Agosti, in La Prensa, August 11, 1978).

"It would be absurd to suppose that we have won the war against subversion simply because we have removed the armed threat [...] Residual elements of subversion are now appearing in religious, political, educational, economic, cultural and employment spheres" (Suárez Mason, Carlos, in La Prensa, July 7, 1979).

[The guidelines of the National Reorganization Process] "will ratify the clear definition of Argentina as a Western Christian nation. For the Argentine nation has been rooted since its origin in that civilization. Our 
society is united by broad agreement on love of God, homeland, freedom, family, property, justice, peace, law and order" (Brigadier General Graffigna in La Prensa, August 11, 1979).

"I came here from my country, which had just emerged from a long war against the enemies of the nation, against the constant enemies of our civilization, from a war in which I participated intensely by the grace of God" [...] [The subversive act] "without God, without family, without freedom, without hope, without the concept of the beginning and end of Creation, with Satan at their head" (General Omar Riveros, in Le Monde Diplomatique (in Spanish), October 14, 1980 (Speech to the Inter-American Defense Board).

"The nation is a shared sentiment that goes beyond abstract organizations and formal issues. A common destiny [...] We will argue that the nation is a living symbol of identity and of the solidarity of human existence, the full synthesis of a culture and a style. That is why we can speak of a "Western nation" (Camps, Ramon J., in La Prensa, January 30, 1981).

"Almost without our realizing it, Marxist ideology grew without restraint, developed all its mechanisms, and invaded our lives. There was no leadership to stop it, or demagoguery able to prevent the takeover of power, institutions and even Argentine customs. In this context of ideological lawlessness, crisis of intelligence and absence of power, and faced by an all encompassing threat to our spiritual unity, the military carried out the National Reorganization Process" (Camps, Ramon J., in La Prensa, May 17, 1981).

Let it stand as a warning that that those who expressed these thoughts have been convicted or accused of crimes against humanity. The above quotations (from the book "Censura, autoritarismo y cultura: Argentina 1960-1983." (“Censorship, Authoritarianism and Culture: Argentina 1960-1983.”) Andrés Avellaneda. CEDAL, 1986) and whose main ideas have emerged once again in the development of this trial [sic]. It is hard to find a more perverse example of a "reorganization" plan than the theft of children from their families of origin and their delivery to families who agree with the ideology of genocide (Article 2 paragraph e) of the Convention on the Prevention and Punishment of the Crime of Genocide) [sic].

It should be noted in this regard that the evidence collected in this trial, also taking into account the cases tried previously (Bergés - Etchecolatz by this Court; and Case No. 1,351 NICOLAIDES Cristino and other, abduction of minors; Case No.1499 VIDELA Jorge Rafael "deleting the civil status of a minor;" Case No. 2963/09 "Bianco Norberto Atilio, infringement of Arts. 139, 146 and 293 of the Criminal Code;" Case No. 8405/97 "Miara Samuel, supposition of civil status;" Case G. 1015; L. XXXVIII, "Gualtieri Rugnone de Prieto Emma Elidia and other, subtraction under 10 years; - Case 46/85- No", Art 11. / 08/2009 Supreme Court, "Rei, Victor Enrique and other, abduction of minors under 10 years - Art. 146 -;" "Chamber of Criminal Appeals 10/6/10, and Case 9569;" RIVAS, Osvaldo Arturo and other, appeal," Division II of September 8, 2009 - of the Second Division of the CNCP), it is now undisputed that at the time of the events, in a systematic way as part of the plan of extermination conducted by the civilian-military dictatorship in question, the situation described under subparagraph e) of Article 2 of the Convention on the Prevention and Punishment of the Crime of Genocide has also arisen.

In accordance with the aforementioned article and paragraph: "In the present Convention, genocide means any of the following acts committed with intent to destroy, in whole or in part, a national, ethnical, racial or religious group as such: ... e) Forcibly transferring children of the group to another group." [...] Dr. Portela and Dr. Falcone explain that it is impossible to include this offense in the decision-making as that charge was not introduced by the prosecution at the appropriate procedural time. [...]

On those grounds, the Federal Oral Criminal Court No.1 of La Plata RESOLVES: [...]

\section{SECOND:}

1. TO DECLARE that the crimes committed by PUBLIC OFFICIALS under the protection of an ORGANIZED and CLANDESTINE POWER APPARATUS constitute CRIMINAL OFFENSES of "BREACH of SPECIAL DUTY of CARE." Having established this classification, ALL THOSE with a SPECIAL DUTY of CARE regardless of any quantitative description of their contribution to crime, must be held accountable as DIRECT AUTHORS of the crimes for which they are finally convicted. 
2. CONSIDERING that the conduct of the accused, being clearly intended to exterminate a national group, entails the commission of the International Crime of Genocide (as defined by Article 2 a, $\mathrm{b}, \mathrm{c}$ and $\mathrm{e}$ of the Convention on the Prevention and Punishment of the Crime of Genocide, which was ratified by Decree 6,286, in accordance with Art. 118 of the Constitution), a sentence for that offense is appropriate in each case. Notwithstanding the foregoing, by majority, in order not to violate the principle of congruence because the defendants were not investigated for this crime, which was only introduced in the allegations, it is appropriate to apply the categories of crimes and the penalties provided for in domestic law, all of which constitute crimes against humanity, with the full Court in agreement with the latter categorization.

\section{End Notes}

1. The case name of the judgment of Camps Circuit (Circuito Camps) is "ALMEIDA, Domingo y otros s/ Inf. arts. 80, 139, 142, $144,146,45,54$ y 55 del C.P."

2. For example, several other courts have also construed this crimes as genocide: the Case No 1914 "FIOCHETTI y acumulados": "F"-07-TOCFSL, caratulados: "F. s/ Av. Delito (Fiochetti, Graciela)" y sus acumulados Expte. 771-F-06 "Fiscal s/ Av. Inf. Art. 142 bis del Código Penal" (Pedro Valentín Ledesma); Expte. 864-F-06 "Fiscal s/ Av. Infr. Art. 142 bis del Código Penal" (Santana Alcaraz) y Expte. 859-F-06 "Fernández, Víctor Carlos denuncia apremios ilegales" on March 12, 2009 at San Luis, Province of San Luis.; the Case No 2965/09 “ALONSO Omar -HERZBERG, Juan Carlos s/ inf. artículos 139, 146 y 293 C.P." on December 14, 2010 at La Plata, Province of Buenos Aires; the Cases No 1.960/10 "HARGUINDEGUY, ALBANO EDUARDO Y OTROS S/INF. ART. 151 Y OTROS DEL C. PENAL" and N 1.991/10 “DIAZ BESSONE, RAMÓN GENARO Y OTROS S/ INF. ART. 141 Y OTROS DEL C. PENAL", y No 2138/ 11 caratulada: "VALENTINO, JUAN MIGUEL Y OTROS S/ INF. ART. 141 Y OTROS DEL C. PENAL” on December 27, 2012 at Paraná, Province of Entre Ríos.

3. Extracts from the judgment are quoted here in italics followed by the page numbers. For the complete judgment (in Spanish), see: http://analisispracticasgenocidas.sociales.uba.ar/files/2013/04/SENTENCIA-CAUSA-2955.pdf

4. Ramón Camps was an Argentine army officer who reached the rank of Brigadier General. He was the chief of police of the Province of Buenos Aires and, from 1977 to 1979, head of the Argentine Federal Police. With the return of democracy, Camps was charged and convicted, between 1984 and 1986, for torture followed by murder, anti-Semitism, kidnappings, disappearances, murders, child abductions. In 1990 he was pardoned by President Carlos Menem, and released. Camps died in 1994.

5. For more information regarding the role of this team: http://www.eaaf.org/

6. Montoneros was a Peronist armed political group, active in the 1970s and outnumbered other political organizations. They were relentlessly persecuted by the civil-military dictatorship.

7. Ibérico Saint Jean was an Argentine army general. He was the de facto ruler of the Province of Buenos Aires between 1976 and 1981. On one occasion, in 1977, he declared: "First we will kill all the subversives, then we will kill their collaborators, then their sympathizers, then those who remain indifferent, and finally we will kill the timid."

8. We would like to point out that other civilians were also being tried for their actions during the dictatorship, including the then Economy Minister José Alfredo Martínez de Hoz, prosecuted for his role in the kidnapping of businessmen. Under house arrest since 2010, he died in March 2013 without being sentenced. For more information (in Spanish), see http://www.pagina12.com.ar/diario/ultimas/20-215954-2013-03-16.html

9. Deputy Commissioner in charge of the Directorate General of Investigations of the Buenos Aires provincial police, with power over life and death. He was sentenced to life imprisonment in this trial.

10. Further information on these issues can be found in: Feierstein, Daniel, El genocidio como práctica social. Entre el nazismo y la experiencia argentina (2007 Fondo de Cultura Económica: Buenos Aires); and Paoletti, Alipio, Como los nazis, como en Vietnam: los campos de concentración en la Argentina (1987 Madres de Plaza de Mayo: Buenos Aires).

11. La Nación is an Argentine broadsheet. It has been published since 1871 and is characterized by its conservative line. La Nación was allegedly involved in the case of the newsprint paper mill Papel Prensa expropriated during the military dictatorship and later acquired by the newspaper Clarin. In this case, General Camps had an operational role in the kidnapping and torture that allegedly led to the expropriation.

12. Translator's note: Papel Prensa was bought in 1973 by David Graiver, the banker of the Montoneros guerrilla group for whom Graiver reportedly laundered US $\$ 17$ million from illicit activities, principally kidnapping. Graiver himself died in a plane crash in Acapulco in 1976. His widow, Lidia Papaleo, returned to Argentina on September 16, 1976 and was ordered by the dictatorship to sell her family's stake in Papel Prensa. She was also coerced by the Montoneros, who sought to recover the US\$17 million managed by Graiver. A military tribunal sentenced Papaleo and Graiver's brother and father to 15 years' imprisonment, though an appeals court later cleared the defendants of all charges. Lidia Papaleo declared in 2010 that she had been coerced in 1976 into selling her shares in Papel Prensa, but shortly afterwards changed her testimony, stating that she had only been pressured but not threatened. She also declared she had been paid US $\$ 7,000$ for her shares before being illegally detained by Miguel Etchecolatz and Ramón Camps on March 14, 1977. Unfortunately, this case has been compromised by the current government in its campaign to stifle press freedom after Clarín and La Nación supported a massive farmers strike in 2008. None of this, of course, exonerates Etchecolatz and Camps from other crimes of genocide. 